\title{
Comparative Study of Essential Elements in Parts of Moringa oleifera Plant as Promedicine
}

\author{
*1JAMES, DO; ${ }^{2}$ MAAJI, SP; ${ }^{3}$ GIMBA, CG,${ }^{4}$ TSAKU, JE, ${ }^{5}$ KEVIN, EU \\ ${ }^{1,5}$ Department of Chemistry, Ahmadu Bello University, Zaria. \\ ${ }^{2}$ Department of Chemistry, Federal University Wukari, Nigeria \\ ${ }^{3,3}$ Nigerian Institute of Leather and Science Technology (NILEST), Jos, Nigeria \\ *Corresponding Author Email: jamesdanieloguche@gmail.com; Tel: +2347037868612
}

\begin{abstract}
This study presents the mineral composition of the parts of Moringa oleifera in Zaria. Samples of the parts were wet digested and analyzed for various minerals using Varian Instrument AA240FS for the atomic absorption spectrophotometry (AAS). The contents of $\mathrm{Zn}, \mathrm{Fe}, \mathrm{Ca}, \mathrm{Cu}$ and $\mathrm{Mg}$ in the parts (roots, stem barks, pods, seed cases/shell, seeds and leaves) of Moringa oleifera were found to be 0.096, 0.872, 12.317, 0.008 and $2.076 \mathrm{mg} / \mathrm{g}$ in the roots respectively; $0.022,0.412,0.29 .397,0.005$, and $3.729 \mathrm{mg} / \mathrm{g}$ in the stem barks respectively; $0.021,0.017,8.048,0.003$ and $1.827 \mathrm{mg} / \mathrm{g}$ in the pods respectively; $0.019,0.056,6.467,0.002$, and $1.551 \mathrm{mg} / \mathrm{g}$ in the seed cases/shells respectively; $0.017,0.029,4.217,0.001$ and $1.616 \mathrm{mg} / \mathrm{g}$ in the seeds respectively and in the leaves $0.017,0.205,19.974,0.005$ and $2.494 \mathrm{mg} / \mathrm{g}$ respectively. The contents of different minerals in the parts of M. oleifera varied from parts to parts. This variation in the contents of various minerals within the parts might be attributed to the variable uptake of minerals by the plant material and variable agro-climatic conditions of the subject region. The results of the present analysis revealed that parts of M. oleifera contained a considerably high amount of $\mathrm{Zn}, \mathrm{Fe}, \mathrm{Ca}, \mathrm{Cu}$ and $\mathrm{Mg}$ that can be used as a viable supplement of medicinal and dietary minerals which makes it a promising pro-medicine.
\end{abstract}

\section{DOI: https://dx.doi.org/10.4314/jasem.v23i8.12}

Copyright: Copyright $($ C 2019 James et al. This is an open access article distributed under the Creative Commons Attribution License (CCL), which permits unrestricted use, distribution, and reproduction in any medium, provided the original work is properly cited.

Dates: Received: 17 June 2019; Revised: 27 July 2019; Accepted 18 August 2019

Keywords: Minerals, oleifera, dietary-supplements

Plants are the richest bio-resource of drugs of traditional systems of medicine, modern medicines, nutraceuticals, food supplements, folk medicines, pharmaceutical intermediates and chemical entities for synthetic drugs. It is estimated that today, plant materials are present in, or have provided the models for 50\% Western drugs; Hammer, (1999). Minerals cannot be synthesized by animals and must be provided from plants or mineral-rich water; Mosha et al., (1995). Living organisms use minerals for osmotic adjustment; activate enzymes, hormones and other organic molecules that enhance the growth, function, and maintenance of life processes Aslam, et al., (2005). Human bodies daily need more than $100 \mathrm{mg}$ of major minerals and less than $100 \mathrm{mg}$ of minor minerals Rajangam, et al., (2001). Mineral composition of a plant plays a significant role in its nutritional, medicinal and therapeutic values, Al-Kharusi, et al., (2009). It was reported that mineral content in the leaves, pods, seeds, stem barks and roots of Moringa varied in Pakistan with location; Aslam, et al., (2005). Moringa oleifera is grown and widely cultivated in the northern part of Nigeria and many countries in tropical Africa. M. oleifera can be grown in a variety of soil conditions preferring well-drained sandy or loamy soil that is slightly alkaline; Abdul, (2007). Almost every part of M. oleifera can be used for food and as forage for livestock; Ram, (1994). The leaves can be eaten freshly cooked or stored as dried powder for several months, the pods when young can be cooked; eaten like beans; National Research Council (2006). Its oil and micronutrients have been reported to contain antitumor, antiepileptic, antidiuretic, antiinflammatory, and venomous bite characters; Hsu, (2006). According to Anwar et al., (2007), Moringa trees have been used to combat malnutrition (especially among infants and breast feeding women) in many developing countries, particularly in India, Pakistan, the Philippines, Hawaii and many parts of Africa. This present research focuses on the comparative determination of some essential elements in parts of Moringa oleifera plant in Sabon Gari, Zaria as a nutritional supplement potential pro-medicine.

\section{MATERIALS AND METHOD}

Plant Samples Collection: Fresh leaves, pods, seeds, seed cases/shells, roots and stem barks of Moringa oleifera were obtained from mature Moringa oleifera plants in Sabon Gari environs in Zaria city. 
Preparation of Samples: The sample materials (leaves, pods, seeds, seed cases/shells, roots, and stem barks) collected were dried at room temperature for 2-3 weeks to constant weight. The dried plant parts were separately ground to a fine powder.

Wet Digestion: $0.5 \mathrm{~g}$ of each of the samples were weighed into separate beakers and treated with $7.5 \mathrm{~cm}^{3}$ of concentrated $\mathrm{HNO}_{3}$ and $2.5 \mathrm{~cm}^{3}$ of $\mathrm{HCl}$ then heated on an electric hot plate at $70-90{ }^{\circ} \mathrm{C}$ until digestion is complete and the contents of the flasks were cooled, diluted appropriately with deionized water and filtered through Whatman No 42 filter paper into the sample rubbers and made up to volume of $50 \mathrm{~cm}^{3}$ with deionized water respectively.

Mineral Analysis: Mineral contents were determined by the Association of Official Analytical Chemists methods (AOAC, 1990)20). The wet digested samples were taken for instrumental analysis using Varian Instrument AA240FS for the atomic absorption spectrophotometry (AAS).

Working standard solutions of $\mathrm{Ca}, \mathrm{Mg}, \mathrm{Fe}, \mathrm{Cu}$, and $\mathrm{Zn}$ were prepared from stock standard solution (1000 $\mathrm{mgL}^{-1}$ ) and absorbance was obtained for a various working standard for each element in the samples using atomic absorption spectrometer (Sahito et al., 2002). The absorbance was plotted against concentration and the linear calibration curves formed revealed the real concentration of each sample. A blank reading was also taken and the necessary correction was made during the calculation of the concentration of various elements.

\section{RESULTS AND DISCUSSION}

The results of the present analysis presented in figures $1,2,3,4$ and 5 respectively show that the concentrations of $\mathrm{Zn}, \mathrm{Fe}, \mathrm{Ca}, \mathrm{Cu}$ and $\mathrm{Mg}$ in the samples of $M$. oleifera roots were found to be 0.096 , $0.872,12.317,0.008$ and $2.076 \mathrm{mg} / \mathrm{g}$, respectively. In the samples of the $M$. oleifera stem barks, the concentrations of $\mathrm{Zn}, \mathrm{Fe}, \mathrm{Ca}, \mathrm{Cu}$ and $\mathrm{Mg}$ were found to be $0.022,0.412,0.29 .397,0.005$, and $3.729 \mathrm{mg} / \mathrm{g}$ respectively. In the samples of the $M$. oleifera pods, the concentrations of $\mathrm{Zn}, \mathrm{Fe}, \mathrm{Ca}, \mathrm{Cu}$ and $\mathrm{Mg}$ were found to be $0.021,0.017,8.048,0.003$ and $1.827 \mathrm{mg} / \mathrm{g}$ respectively. The Moringa oleifera seed cases/shells sample contains the concentration of $\mathrm{Zn}, \mathrm{Fe}, \mathrm{Ca}, \mathrm{Cu}$ and $\mathrm{Mg}$ as $0.019,0.056,6.467,0.002$, and $1.551 \mathrm{mg} / \mathrm{g}$ respectively. In the samples of the $M$. oleifera seeds, the concentrations of $\mathrm{Zn}, \mathrm{Fe}, \mathrm{Ca}, \mathrm{Cu}$ and $\mathrm{Mg}$ were found to be $0.017,0.029,4.217,0.001$ and $1.616 \mathrm{mg} / \mathrm{g}$ respectively.

In the samples of the M. oleifera leaves, the concentration of $\mathrm{Zn}, \mathrm{Fe}, \mathrm{Ca}, \mathrm{Cu}$ and $\mathrm{Mg}$ were found to be $0.017,0.205,19.974,0.005$ and $2.494 \mathrm{mg} / \mathrm{g}$ respectively.

God has given us everything we need most especially, for health and nutrition; the problem is that we prefer synthetic remedies, we fear powerful healing plants (herbs), and we fear what is natural. The root sample has the highest contents of $\mathrm{Zn}$ while the seeds and leaves have the lowest content of $\mathrm{Zn}$; the root has the highest contents of $\mathrm{Fe}$ while the pods have the lowest; the stem barks has the highest content of $\mathrm{Ca}$ while the seed sample has the lowest; the root has the highest contents of $\mathrm{Cu}$ while the seeds sample has the lowest and the stem bark sample has the highest contents of magnesium while the seeds and the seed cases/shells have relatively the lowest amount of magnesium. Calcium helps in transporting long-chain fatty acid which helps in preventing heart diseases, high blood pressure, and other cardiovascular diseases. Calcium, $\mathrm{Ca}$ helps in the formation of bone and teeth, blood clothing and nerve transmission and its deficiency cause rickets, osteoporosis, and convulsions. Magnesium works with calcium to help to transmit nerve impulse in the brain. It also has a calming effect and works on the nervous system of the people with depression. Magnesium, Mg help in enzyme activation and protein synthesis and its deficiency bring about growth failure behavior problem and spasms (involuntary sudden muscle contraction). Zinc, Zn helps in digestion, sexual reproduction, and cell repair; its deficiency causes growth failure, small sex glands and delay wound healing. Iron, Fe helps in energy metabolism, hemoglobin formation in blood and its deficiency causes anemia. Copper, $\mathrm{Cu}$ help in red blood cell formation and its deficiency causes anemia, impair bone and nervous, tissue development; Julia, (2010).

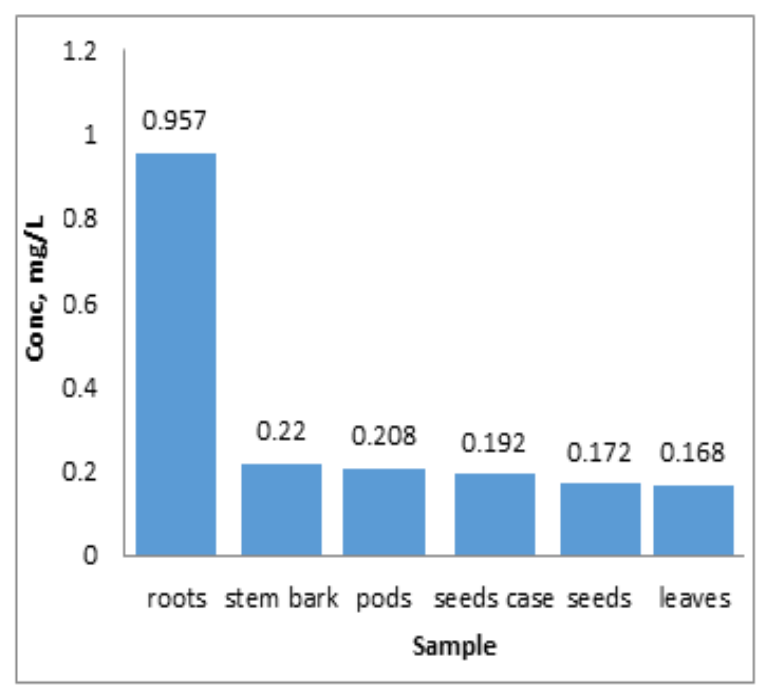

Fig 1. Zinc, Zn content in six parts of Moringa plant (mg/g) 


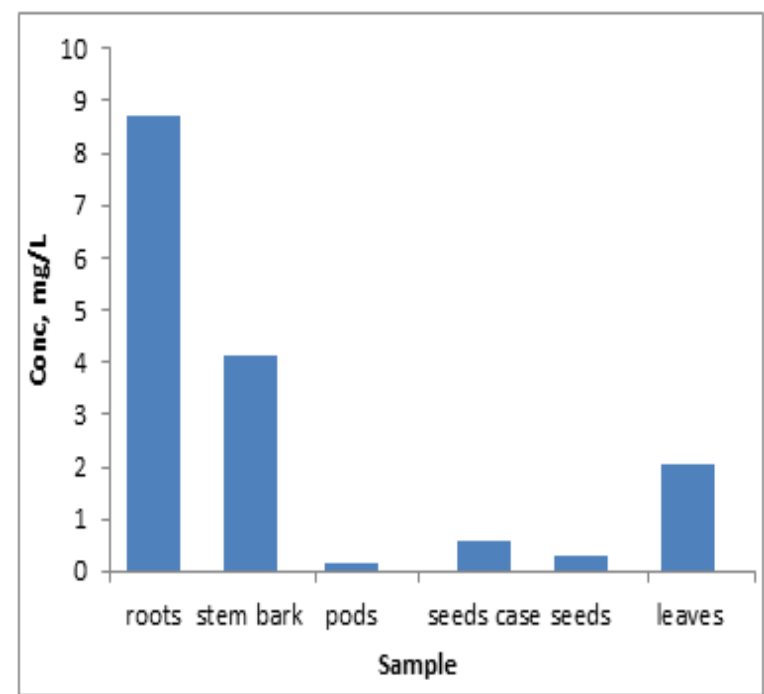

Fig 2. Iron, Fe content in six parts of Moringa plant (mg/g)

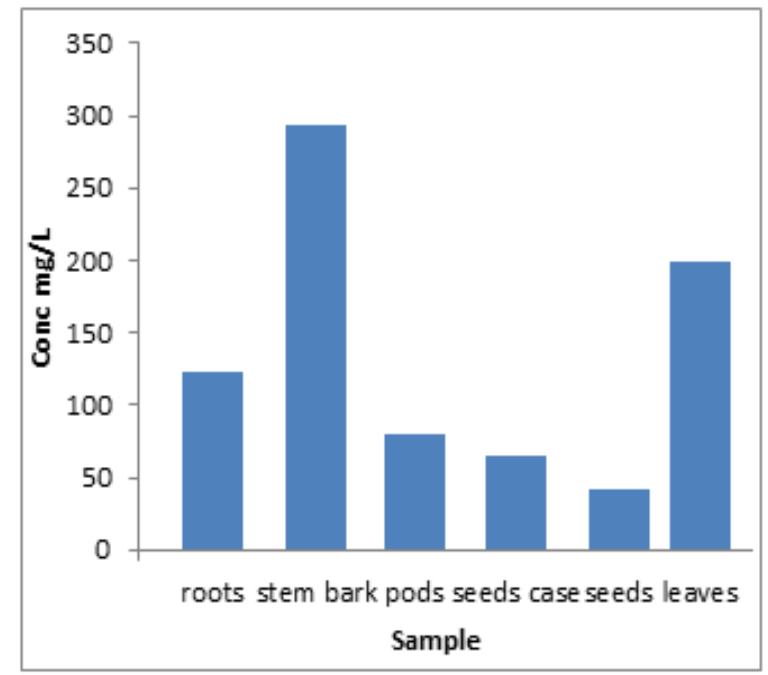

Fig 3. Calcium Ca content in six parts of Moringa plant (mg/g)

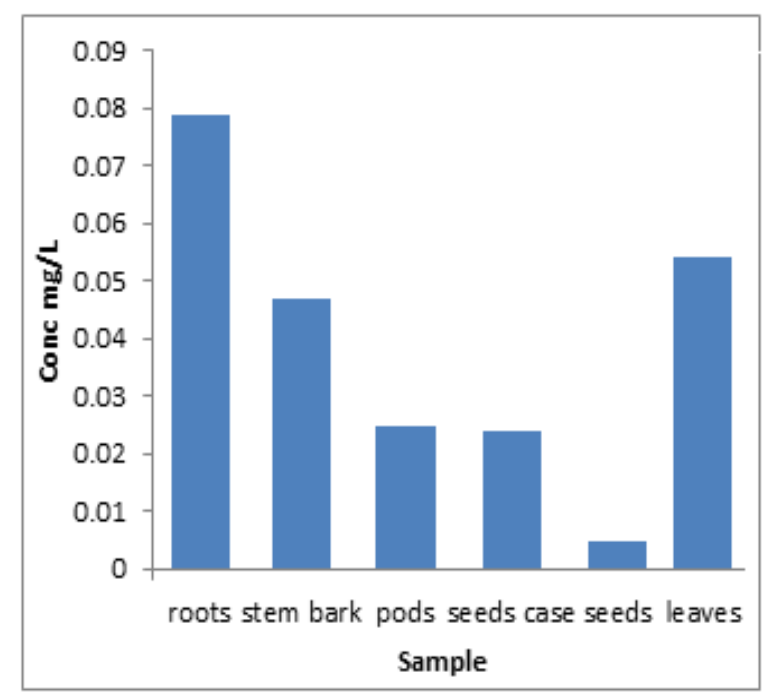

Fig 4. Copper, $\mathrm{Cu}$ content in six parts of Moringa plant (mg/g)

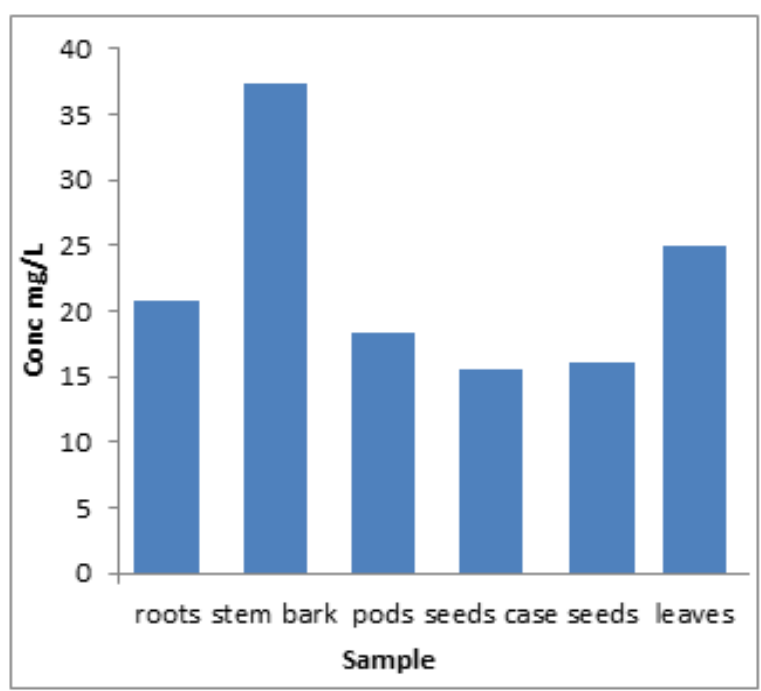

Fig 5. Magnesium. Mg content in six parts of the Moringa plant $(\mathrm{mg} / \mathrm{g})$

The level of copper in the samples of leaves was quite low as compared to other minerals. Prasad (1998) and Onianwa et al. (2001) cited in Anjorin (2010) reported a similar trend of low $\mathrm{Cu}$ content in Nigerian plant dietary intakes. Anwar and Bhanger (2003) cited in Anjorin (2010) similarly reported a relatively low level of $\mathrm{Cu}$ in Moringa leaves and pods in different regions in Pakistan. Only a minute quantity of $\mathrm{Zn}$ was found in the leaf stalk and seed powder. According to Anjorin, et al., (2010); in his research, the Fe content in the seed shell was $0.2436 \mathrm{mg} \mathrm{g}$-Toxic element such as $\mathrm{Pb}$ was absent in the Moringa plant. The results of the present analysis demonstrated a significant variation in the mineral content of the parts of Moringa oleifera. This variation in the contents of various minerals within the parts might be attributed to the variable uptake of minerals by the plant material and variable agro-climatic conditions of the subject region, Zaria. The results of the present analysis revealed that the parts of M. oleifera are a good source of important minerals and these plant parts can be explored as a viable supplement and ready source of dietary minerals in animal and human food as promedicine. The roots and stem bark of moringa contains a high amount of nutritional and medicinal materials than other parts respectively and that makes them used for traditional medicine mostly for curing diseases by native doctors/herbalist.

Conclusion: Moringa oleifera plant is the most inexpensive and credible alternative to not only providing nutrition but also cure and prevent a lot of diseases. This research findings unveil that all the parts contain a significant amount of essential elements that make them indispensable pro-medicine, fight 
problems of malnutrition, diseases, and unemployment by utilizing its full benefits.

\section{REFERENCES}

Abdul, DAS, (2007). Economic Importance of Moringa oleifera in Tafa Local Government Area of Niger State, p: 34. NDE Project, Federal College of Forestry Mechanization, Kaduna, Nigeria.

Adewusi, SR; Ojumu, TV; Falade, OS (1999). The Effect of Processing on Total Organic Acids Content and Mineral Availability of Simulated Cassava-vegetable Diets. Plant Foods Hum. Nutr., 53: 367-380.

Al-Kharusi, LM; Elmardi, MO; Ali, A; Al-Said, FAJ; Abdelbasit, KM; Al-Rawahi, S (2009). Effect of Mineral and Organic Fertilizers on the Chemical Characteristics and Quality of Date Fruits. Int. J. Agric. Biol., 11: 290-296.

Anjorin, TS; Ikokoh, P; Okolo, S (2010). Mineral composition of Moringa oleifera leaves, pods, and seeds from two regions in Abuja.

Anwar, F; Bhanger, MI (2003). Analytical Characterization of Moringa oleifera Seed Oil Grows in Temperate Regions of Pakistan. J. Agric. Food. Chem., 51: 6558-6563.

Anwer, T; Kazi, TG; Bhanger, MI; Anwar, F; Iqbal, RS (2003). Determination of Trace Metals in Non-concentration Oil Seeds and Oil being Resources by AAS. Pak. J. Anal. Chem., 4: 145151.

Aslam, M; Anwar, F; Nadeem, R; Rashid, U; Kazi, TG; Nadeem, M (2005). Mineral Composition of Moringa oleifera Leaves and Pods from Different Regions of Punjab, Pakistan. Asian J. Plant Sci., 4: 417-421.

Booth FEM; Wickens, GE (1988). Non- timber Uses of Selected Arid Zone Trees and Shrubs in Africa.FAO Conservation Guide 19, Rome, Food and Agriculture Organization, 176.

Dahl, LK (1972). Salt and Hypertension. Am. J. Clin. Nutr., 25: 231-238.

Fuglie, LJ (1999). The Miracle Tree: Moringa oleifera: Multiple Attributes of Moringa. Dakar, Senegal: Church World Service.
Hammer, KA; Carson, CF; Riley, TV (1999). Antimicrobial Activity of Essential Oils and Other Plant Extracts. J. Appl. Microbiol. 86, 985-990.

Hsu, R (2006). Moringa Oleifera Medicinal and Economic Uses. International course on Economic Botany. National herbarium, Leiden, The Netherlands.

Johnson, BC (2005). Clinical Perspectives on the Health Effects of Moringa oleifera: A Promising Adjunct for Balanced Nutrition and Better Health. KOS Health Publications

Julia, C (2010). Study of Nutritional and Medicinal Values of Moringa Leaves

Monica G. Marcu, (2005). Miracle Tree, KOS Health Publications

Mosha, TC; Pace, RD; Adeyeye, S; Mtebe, K; Laswai, H (1995). Proximate Composition and Mineral Contents of Selected Tanzanian Vegetables and Effect of Traditional processing on the Retention of Ascorbic acid, Riboflavin in and Thiamine. Plant Food Hum. Nutri, 48: 235-245.

Mossa, JS (1985). A Study on the Crude Antidiabetic Drugs Used in Arabian Folk Medicine. Int. J. Crude Drug Res. 23:137-145.

National Research Council, (2006). "Moringa", Lost Crops of Africa, Vol. 2. Vegetables Lost Crop of Africa, 2 National Academics Press.

Nikkon, F; Saud, ZA; Rehman, MH; Haque, ME (2003). In Vitro Antimicrobial Activity of the Compound Isolated from Chloroform Extract of Moringa oleifera Lam. Pak. J. Biol. Sci. 22: 1888-1890.

Rajangam, J; Azahakia, MRS; Thangaraj, T; Vijayakumar, A Rajurkar, NS; Damame, MM (1998). Mineral Content of Medicinal Plants Used in Treatment of Diseases Resulting from Urinary Tract Disorders. Biol. Trace Elem. Res., 65: 251-259.

Rajurkar, NS; Damame, MM (1998). Mineral Content of Medicinal Plants Used in Treatment of Diseases Resulting from Urinary Tract Disorders. Boil. Trace. Elem. Res., 65: 251-259.

Rajurkar, NS; Damame, MM (1998). Mineral Content of Medicinal Plants Used in Treatment of 
diseases resulting from Urinary tract disorders. Biol. Trace Elem. Res., 65: 251-259.

Ram, J (1994). Moringa: A Highly Nutritious Vegetable Tree. Tropical Rural and Island/Atoll Development, Experimental Station (TRIADES), Technical Bulletin No. 2.

Ramachandran, C; Peter, KV; Gopalakrishnan, PK (1980). Drumstick (Moringa oleifera): A Multipurpose Indian Vegetable. Economic Botany 34(3):276-283.
Reedy, NS; Bhatt, G (2001). Contents of Minerals in green leafy vegetable cultivated on soil fortified with different chemical fertilizer. Plant Food Hum. Nutri., 5: 1-6

Robbers, J; Speedie, M; Tyler, V (1996). Pharmacognosy and Pharmacobiotechnology. Williams and Wilkins, Baltimore, 1-14. 